\title{
The Impact of the European Refugee Crisis on the Popularity of Greece, Italy and Spain as Tourist Destinations
}

\author{
Blanka HAVLÍČKOVÁ \\ University of Economics, Prague, Czech Republic \\ blanka.havlickovalvse.cz
}

\begin{abstract}
In 2015 more than a million of migrants from the Middle East and Africa have appeared on the shores of Greece, Italy and Spain, after successfully taking the Mediterranean routes to the dream continent. The unpreparedness of the EU as well as high numbers of the newcomers caused among others the fear of refugees in the Czech Republic. The aim of this study is to find out if there is a negative dependency between the numbers of incoming migrants to the countries of southern Europe and the long-term stays in these countries by the Czech population and to confirm or combat the hypothesis that the increase in the number of refugees arriving at the shores Greece, Italy and Spain has decreased the popularity of these countries as tourist destinations among Czech citizens. The study is based on data of the UNHCR, the Czech Statistical Office and the Institute of Sociology at Academy of Sciences of the Czech Republic.
\end{abstract}

Keywords: European Refugee Crisis, Tourism, Regional Development.

\section{Introduction}

Tourism has long been one of the world's leading industries, generating revenue over $\$ 1$ trillion a year worldwide, and ranks among the leading export industries. Tourism does not, however, prosper in places that are perceived as dangerous. The sense of personal safety is one of the basic conditions for the development of a popular tourist destination, region or country. [10] It could have been also the perception of security risks, namely the risks associated with the arrival of refugees to south European shores, which could have influenced the decisions of Czech consumers on spending their holidays in years 2015 and 2016.

The definition of a refugee is defined in the international law as according to the Convention on the Status of Refugees as follows: "A person who is outside his or her country and has legitimate fears of persecution for racial, religious or national reasons or for reasons of belonging to certain social strata or for having certain political views and is refused to be protected in his homeland; The same applies to a stateless person who is outside the country of his previous residence as a consequence 
of the aforementioned events and who, due to the above mentioned fears, does not want or cannot return." [6] The amount of refugees globally in 2015 was the highest since World War II. [1] [17] The largest source of refugees was the war in Syria, which resulted in 4.9 million refugees by the end of 2015 . Worldwide, Turkey has hosted the largest portion of refugees in 2015, about 2.5 million people. [21]

From Turkey, refugees mostly followed the Eastern-Mediterranean route (putting pressure mostly on Greece and Bulgaria), then followed by the so-called WesternBalkan route through Greece to other European Union countries. The Western Balkan route was used by the majority of refugees, who tried to reach countries of the European Union putting a big pressure on Greece (red and purple lines of the following picture). For example, only during one month (August 2015) 228,967 left Turkey to Europe though the Eastern Mediterranean route (red line of the following picture) and 155,120 people continued their journey through the Western Balkans Route to Central Europe. Little less, but still popular route to Europe was the Central Mediterranean Route (green line of the following picture). Only in August 2015, about 106,341 people used this green line route to reach European Union, specifically Italy. Thousands of migrants have used Western Mediterranean Route (blue line of the following picture). Compared with the other routes, however, the blue route was not so busy. About 7,892 people used the blue line route to reach European Union, specifically Spain in August 2015. This is about 29 times less migrant traffic than in the Eastern Mediterranean route and 13.5 times less traffic than in the Central Mediterranean Route. [18] [21]



Fig. 1. Map of major migrant routes to the countries of the European Union.

In 2015 the largest wave of refugees heading from the Middle East to the EU borders arrived causing surprise and instability in some European countries, which were unprepared and unable to come to a common ground as to how to deal with this 
migration wave. Therefore refugees arrived in Europe in an uncontrolled manner, their deployment within the European Union was not centrally managed and there was a considerable heterogeneity among the member states in system of handling with the incomings. The arrival of refugees has in many member states resulted in political conflicts, social tensions, the mobilization of extremist-right parties, possible horror scenarios depicted in the media, arson, attacks on asylum centres and partial closure of Schengen borders. [1] [2] [12]

Finally, in 2016, the European Union has managed to calm down the migration wave through a negotiation about the co-operation with Turkey leading to the reduction of incomings and stabilising the migration wave within its own territory. Incoming migrants were mostly from Syria, but a significant proportion of them were from Iraq and Afghanistan. The following graph illustrates the arrival of migrants from each of the countries of Asia and Africa by sea to Greece, Italy and Spain. Most refugees came in the autumn months - September 2015, October 2015 and November 2015. [19] 


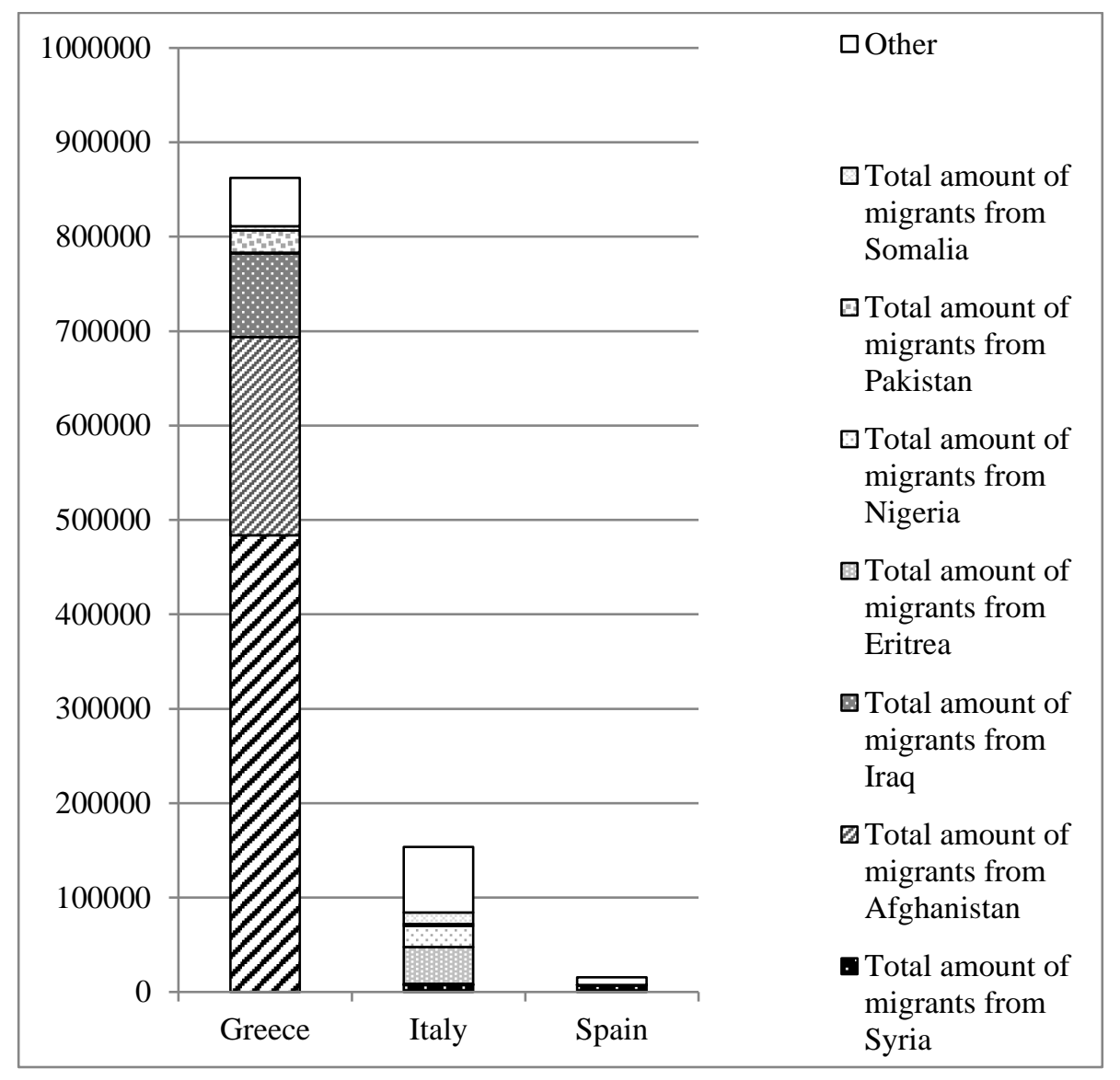

Fig. 2. Admission of migrants by nationality to the individual countries of southern Europe from January to December 2015.

\section{Theoretical basis}

Modern theories describe a dual process, or two different systems, the individual evaluates the information and then the risk itself, in our case, the fear of refugees or migrants. [3] [7] [13] One of these evaluation systems has a natural evolution in man and resembles an animal instinct - it is fast, automated and therefore not too accessible to conscious perception and control. This system works primarily on the basis of similarities, associations, and includes the whole range of emotions that serve as the first warning system. [14] [16]

The second system processes information and evaluates risk based on algorithms and probability rules, Bayesian updates and formal logic. For this reason, the second 
system is slower, more demanding, and requires full awareness, including conscious control. The second system is also more abstract. [14] [15] The illustrative distribution of the two information processing systems on which the risk is assessed is plotted in the following table:

Table 1. Explanation of the difference in risk assessment for System 1 and System 2.

\begin{tabular}{ll}
\hline System 1 & System 2 \\
\hline Fast & Slow \\
Automatic & Controllable \\
Does not require effort & Requires effort \\
Based on associations & Based on rules \\
Emotional & Advisory \\
\hline
\end{tabular}

Many studies have already documented that perception of risk is influenced by associations and emotions similarly stronger or even stronger than their own reason and a conscious evaluation of probability rules. The two systems mentioned above (System 1 and System 2) are involved in the risk assessment, and the risk is far from being rational. On the other hand, in the case of strong impulses, such as concerns about their own security, there is more frequent emotional processing in the ordinary population than the conscious processing of the likelihood that the risk of repetition of a given terrorist attack will be evaluated. [14] The involvement of emotions in decision making has also been demonstrated by laboratory neurobiology experiments. [5]

Generally, people tend to overestimate the importance of events and information that are suggestive, emotional, recent, recurring often, or most often occurring in memory. As noted in 1974 by a psychologist and later famous Nobel Prize winner for economics, Daniel Kahneman it is common for a subjective perception of the probability of a traffic accident to increase temporarily when we pass a car roof down at the highway - such a situation creates a specific cognitive framework under which people interpret further information. One tends to assess the relative importance of things according to the ease with which they are remembered - and this is largely influenced by the extent of coverage of the matter in the media. Frequently mentioned topics in people's minds remain, while others leave. [7]

The Czech Republic was one of the countries to which the influx of refugees from the countries of the Middle East and Africa has not had a real impact and the number of asylum seekers has not risen significantly. [1] The Czech Republic doesn't lie on the so called Western Balkan route, preventing the main stream of refugees from the entrance.

Despite the fact, that there was not the influx of refugees in the Czech Republic through the role of the media the migratory wave caused a great social tension, the mobilization of extremist right-wing parties and enormous public concern. The following table presents the most frequently expressed fears of the Czech public in 2010 and 2015 according to the Institute of Sociology. 
Table 2. Survey of fears among the Czech public (from a wide range of respondents, the respondents always chose the two worries they feel the most, for the purposes of this article the table was shortened to some concerns).

\begin{tabular}{lcc}
\hline $\begin{array}{l}\text { Concerns of the Czech } \\
\text { population }\end{array}$ & $\begin{array}{l}\text { Expressed as a } \\
\text { percentage in 2010 }\end{array}$ & $\begin{array}{l}\text { Expressed as a } \\
\text { percentage in 2015 }\end{array}$ \\
\hline Migration, refugees & $0 \%$ & $31 \%$ \\
Illness & $20 \%$ & $12 \%$ \\
Unemployment & $31 \%$ & $9 \%$ \\
$\begin{array}{l}\text { Concerns about family, } \\
\text { children, partner, friends, }\end{array}$ & $14 \%$ & $3 \%$ \\
$\begin{array}{l}\text { about their health } \\
\text { Crime, security }\end{array}$ & $9 \%$ & \\
Terrorism & $5 \%$ & $11 \%$ \\
Muslim world & $0 \%$ & $36 \%$ \\
\hline
\end{tabular}

The table above shows that while in 2010 the Czech public did not perceive the problem of migration with great concern almost at all, in 2015, the migration was among the main concerns of almost one third of the respondents of the Sociological Institute. The fears of terrorism (fears of 5\% of respondents in 2010 rose to $36 \%$ of respondents in 2015) and fears of the Muslim world (in 2010 respondents of the Sociological Institute felt no concern at the Muslim world at all, while in 2015 This was expressed by $12 \%$ of respondents). It was terrorism and the Muslim world that were closely related to the fears of the refugees, who mostly came from the Muslim world and were media-blamed for some terrorist attacks. The importance of migration concerns in 2015 should not be underestimated, as they often exceeded concerns about illness, family, children, partners, friends, etc. [8]

The next part of this study will focus on whether and to what extent the impact of Czech citizens' fears of migration and refugees has been reflected in their interests to travel to Greece, Italy and Spain, popular vacation destinations that have also became the gates to Europe for refugees.

\section{$3 \quad$ Methodology}

Besides the summary of the current knowledge about the European refugee crisis in 2015 the aim of this article is based on the data about the outbound tourism confirm or combat the hypothesis that because of the commonly spread fear of refugees in the Czech Republic (reported by the Institute of Sociology ASCR) the Czech outbound tourism to Greece, Italy and Spain is negatively correlated with the amount of incoming refugees to these countries. For the purpose of this analysis data of the Czech Statistical Office about outbound tourism of Czech citizens between years 2013 and 2016 and data of UNHCR from the years 2015 and 2016 are used. First of all, we look at the development of amount of incoming migrants to Greece, Italy and Spain and then we look at the development of Czech outbound tourism in Greece, Italy and Spain to see if there is a clear negative dependency between these variables. 


\section{$4 \quad$ Results}

This part of study analyses results of the European refugee crisis on the popularity of all three researched destinations: Greece, Italy and Spain.

\subsection{Refugee crisis and Czech outbound tourism to Greece}

The most popular gateway to Europe was Greece for refugees in 2015. Over 800,000 refugees and migrants came via the Aegean Sea from Turkey into Greece, accounting for 80 per cent of the people arriving irregularly in Europe by sea in 2015. [19] This is a huge increase in the number of incoming refugees. For example, between January and September 2014, refugees in Greece have also penetrated, but in significantly smaller numbers - in the 9 months January-September 2014 there were 43,500 incoming refugees to Greece. [20] Between 2014 and 2015, when there was a huge increase in the number of incoming refugees, there was a noticeable decline of Czech tourists in this destination. Between 2014 and 2015, the total number of Czech longterm stays in Greece decreased from 291,000 in 2014 to 253,000 in 2015, or by $13 \%$ and the total number of Czech overnight stays decreased from 2,895,000 in 2014 to $2,061,000$ in 2015 or by $28 \%$.

In 2016, the situation in Greece has stabilized in the context of the refugee crisis. In January and February 2016, over 123,000 migrants landed in Greece, but in March followed the EU-Tukey deal and the number of migrants arriving in Greece dropped to 26,460, less than half the figure recorded in February. This downward trend continued in April, when only 2,700 migrants arrived in Greece, decreasing by $90 \%$ compared to the previous month and this trend has been maintained. Together with the decrease in the number of incoming refugees, the number of long-term stays by the Czech population began to rise slightly again in 2016 . The total number of longterm stays of the Czech population increased from 253,000 in 2015 to 265,000 in 2016 , or by $4.7 \%$ and the total number of overnights in thousands has increased from $2,061,000$ in 2015 to $2,285,000$ in 2016 , or by $10.8 \%$. [4] 


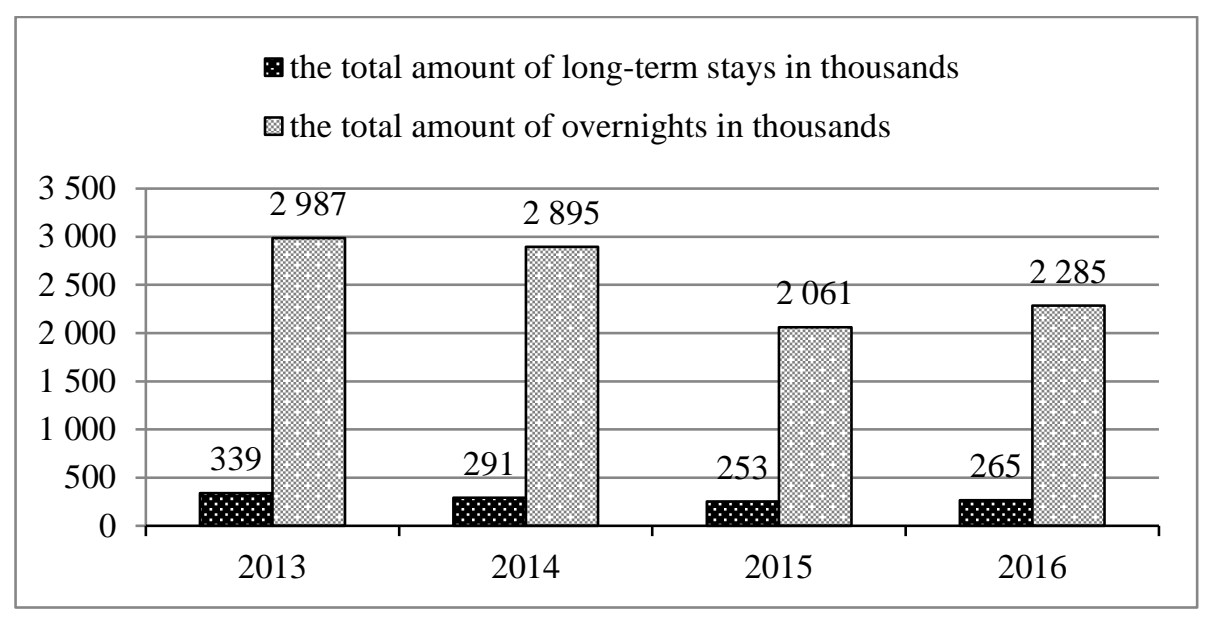

Fig. 3. Development of the Czech outbound tourism to Greece

\subsection{Refugee crisis and Czech outbound tourism to Italy}

The next most popular route to Europe was the Central Mediterranean route, leading form Africa to Sicily, Sardinia or the other Italian island Lampedusa. Total arrivals of refugees to Italy in 2014 in reached 170,100 and in 2015 reached 153,842 (almost six times less than refugee arrivals to Greece in 2015). [19] [20] It is also important to note that information about Italian refugee crisis in 2014 were no covered much in Czech media and the flow of refugees to Sicily and Lampedusa has not got much attention until 2015. Between 2014 and 2015 the total number of long-term stays of the Czech population has decreased from 553,000 in 2014 to 497,000 in 2015, or by $10.2 \%$, the total number of overnights decreased from $4,192,000$ to $3,741,000$, or by $10.7 \%$.

In the year 2016 the refugee flow to Italy hasn't stabilised in the same was at the refugee flow to Greece. The EU-Turkey deal from March 2016 has not prevented the migrant traffic on the central Mediterranean route and had exactly the opposite effect than in the case of Greece. The total amount of incoming migrants to Italy increased in 2016 compared to the year 2015. In 2016 there were 181,436 migrants coming through Central Mediterranean route to Italy (more than to Greece in 2016). [11] It is also important to add, that less than $3 \%$ of the migrants coming to Italy in 2016 were refugees. Despite this fact in the year 2016 we can also observe increase of popularity of Italy as a tourist destination among Czech population. Between 2015 and 2016 the total amount of long-term stays in Italy increased from 497,000 in 2015 to 552,000 in 2016 , or by $11 \%$ and the total number of overnights from $3,741,000$ in 2015 to $4,063,000$ in 2016 , or by $8.6 \%$. [4] 


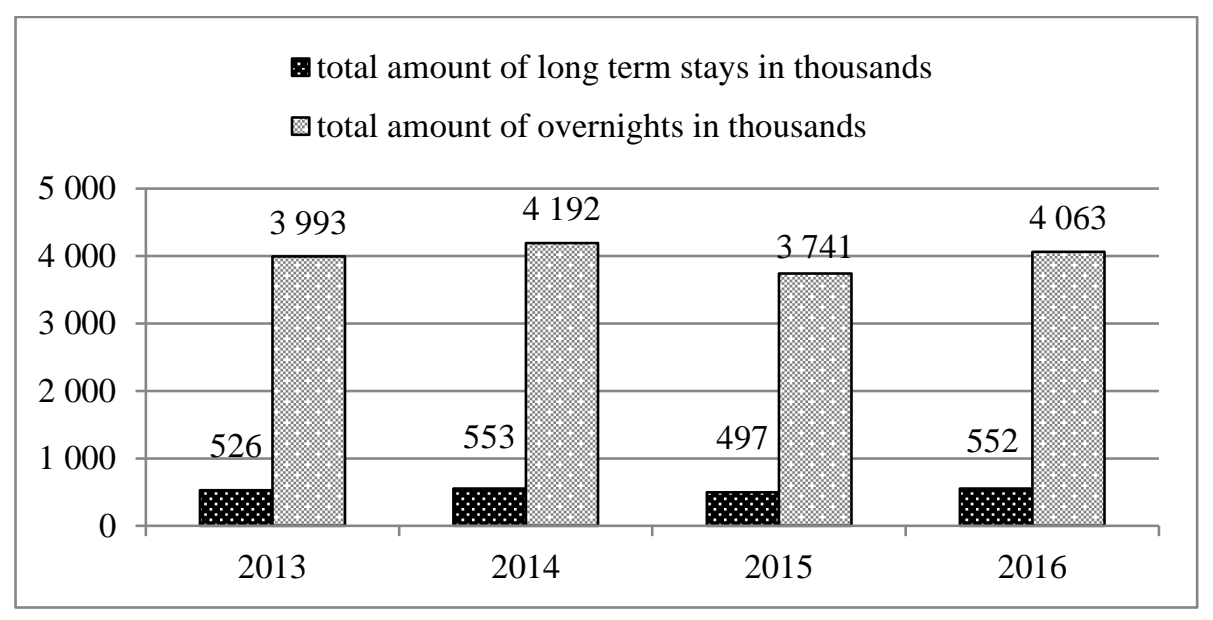

Fig. 4. Development of the Czech outbound tourism to Italy.

\subsection{Refugee crisis and Czech outbound tourism to Spain}

The least used Mediterranean route to Europe during the refugee crisis was the Western Mediterranean route. In 2015, 4,408 migrants came to Spain by sea. In 2016 sea arrivals to Spain increased rapidly with only 7,490 reported migrants for that year. [9] The total number of incoming migrants by sea is relatively low compared to 153,842 and 181,436 arrivals by sea to Italy in 2015 and 2016 and compared to 856,723 and 173,450 arrivals by sea to Greece in 2015 and 2016 . From the perspective of tourism we can observe a huge drop of popularity of Spain in 2015.

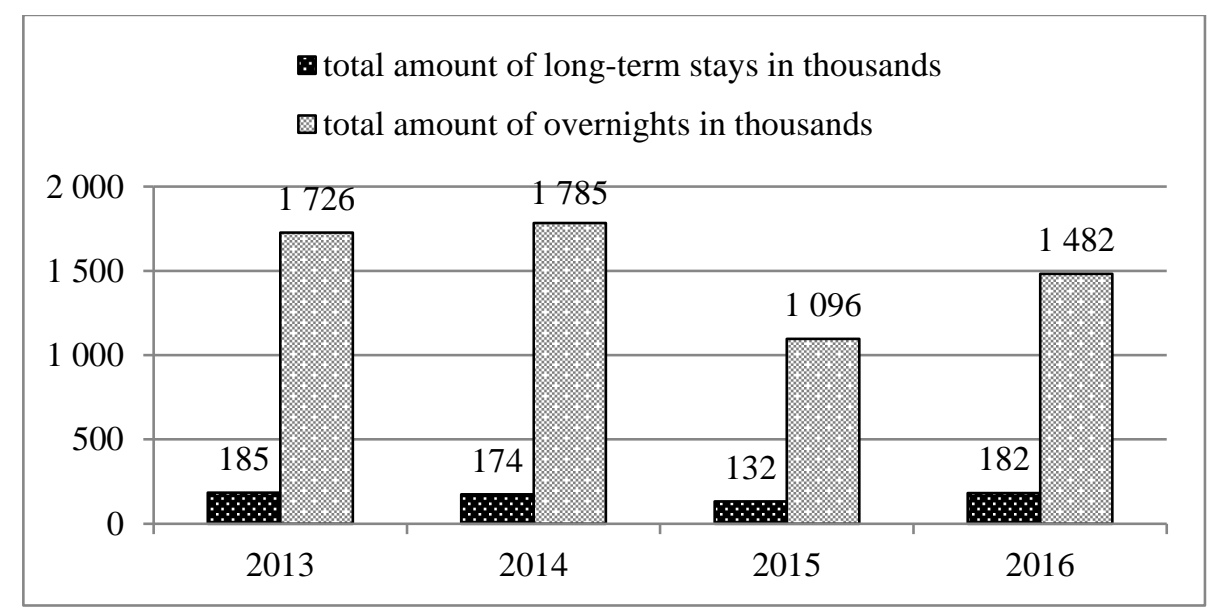

Fig. 5. Development of Czech outbound tourism to Spain. 
Between 2014 and 2015 the total amount of long-term stays decreased from 174,000 in 2014 to 132,000 in 2015 , or by $24.1 \%$ and the total number of overnights decreased from $1,785,000$ in 2014 to $1,096,000$ in 2015 , or by $38.6 \%$.

In 2016, when the amount of migrants coming to Spain by sea increased to 7,490 the popularity of Spain as a tourist destination also increased. The total amount of long-term stays in Spain increased from 132,000 in 2015 to 182,000 in 2016, or by $27.5 \%$. The total number of overnights by Czech population in Spain increased from $1,096,000$ in 2015 to $1,482,000$ in 2016 , or by $26 \%$. [4] [11]

\section{Discussion}

We have to admit that outbound tourism of the Czech population to Greece, Italy and Spain in 2015 and 2016 was not influenced only by the fear of refugees, but also by many different factors. In 2015 the Czech national currency depreciated making purchases abroad relatively more expensive for tourist with the Czech income. At the same time petrol prices dropped in 2015 encouraging travelling by car and therefore to less distant destinations. Because of these and many other factors it is impossible to describe the changes of the Czech outbound tourism to Greece, Italy and Spain just from the perspective of the refugee crisis. We can only search for a dependency between sea arrivals of migrants and long-term stays (4 nights and more) of Czech tourist at the same period, but we cannot imply a direct causality of these events.

\section{Conclusion}

This article summarized the dual process decision-making of tourists as well as the basic facts about the refugee crisis in European Union in 2015, when more than one million of migrants from Africa and the Middle East (mainly Syria) arrived in the European Union (mostly in Greece, but also in Italy and Spain) by sea via the Mediterranean routes. This migratory wave has struck the European Union unprepared causing serious concerns among Czech population. According to the Institute of Sociology ASCR one in three inhabitants of the Czech Republic were reporting the fear of refugees and migrants as their greatest concern in 2015. The reported fear of refugees and the Muslim world among the Czech population by far exceeded fears of illness or fear of losing family members, which depicts the wave of hysteria that occurred in connection with the arrival of migrants in the Czech Republic. The main goal of this study was to find out, if there can be found a negative dependency between amount of migrant's incomings by boats to Greece, Italy and Spain, and Czech outbound tourism to Greece, Italy and Spain, which are normally popular destinations for the citizens of the landlocked Czech Republic.

The analysis of the Czech outbound tourism to Greece, Italy and Spain for the years 2015 and 2016 clearly shows that in 2015, when the refugee crisis has culminated, the number of long-term stays (four nights or more) of the Czech tourists decreased in all researched destinations - Greece Italy and Spain. In March 2016 after 
signing EU-Turkey treaty the number of migrants taking Eastern Mediterranean route and heading to Greece significantly decreased. Therefore it decreased also the amount of migrants using Western Balkan route with the goal of reaching Central European states. While the number of migrants heading to Greece in 2016 due to the EU-Turkey deal has fallen significantly, in Spain and Italy, the number of migrants arriving to the coast by sea has compared to the year 2015 increased and Italy replaced Greece as a main destination for migrants arriving to Europe by sea in 2016. Despite the increase of incoming migrants to Italy and Spain in 2016 the total amount of longterm stays (four nights and more) and the total number of overnights by Czech tourists in Italy and Spain has increased. Therefore we have to reject the hypothesis about the universal negative dependency between the numbers of incoming migrants and total number of Czech outbound tourism to Greece, Italy and Spain. Despite the fact, we cannot see a universal negative dependency; we can see a clearly negative dependency between the number of Czech long-term stays in 2015 and 2016 and the amount of incoming migrants during years 2015 and 2016 in the case of Greece, where the refugee crisis was the most critical until March 2016.

The possible explanation for the absence of negative dependency between amount of incoming migrants and Czech tourists in Italy and Spain can be a relatively lower scale of the problem in Italy and Spain compared to the situation in Greece. Also, the findings of this paper can be influenced by the fact that rather than by the real numbers of incoming migrants, the decision-making of the Czech population was rather emotional and influenced by feelings and impressions received from the media (by System 1 of dual process decision-making). Since the amount of refugees decreased on the Balkan route (neighbouring with the Czech Republic) in the beginning of 2016 the refugee problems could have stopped to look so urgent globally from the Czech perspective.

The statistics of the outbound tourism to Greece, Italy and Spain could have been also influenced by many other factors, which are not connected with the refugee crisis - for example by weakening of the Czech national currency and by the reduction of petrol prices favouring tourism in central - European countries.

Acknowledgements. This article was created within the project IGA "Economic, security and systemic changes in international tourism", no. F2 / 19/2017.

\section{References}

1. Bansak, K., Hainmueller, J., Hangartner, D.: How economic, humanitarian, and religious concerns shape European attitudes toward asylum seekers. Science 354(6309), 217-222. (2016). DOI: 10.1126/science.aag2147.

2. BBC: Migrant crisis, http://www.bbc.com/news/world-europe-34131911, last accessed 2017/08/30.

3. Chaiken, S., Trope, Y.: Dual-Process Theories in Social Psychology. 1st edn. Guilford Press, New York (1999). 
4. Czech Statistical Office: Cestovní ruch - časové řady, https://www.czso.cz/csu/czso/cru_cr, last accessed 2017/12/01.

5. Demasio, A.: Descartes' Error: Emotion, Reason, and the Human Brain. 1st edn. Avon Books, New York (1994).

6. Honuskova, V., Flídrová, E., Janků, L.: Dnes migranti - zítra uprchlíci? Postavení migrantů, kteří potřebují ochranu, v mezinárodním právu. 1st edn. Univerzita Karlova, Právnická fakulta, Prague (2014).

7. Kahneman, D.: Myšlení rychlé a pomalé. 1st edn. Jan Melvil Publishing, Brno (2012).

8. Institute of Sociology: Veřejnost o svých obavách a bezpečnostních rizicích pro Českou republiku,

http://cvvm.soc.cas.cz/media/com_form2content/documents/c1/a7484/f3/ob160112.pdf, last accessed 2017/08/30.

9. IOM: Migrant Arrivals by Sea in Italy Top 170,000 in 2014, https://www.iom.int/news/migrant-arrivals-sea-italy-top-170000-2014, last accessed 2017/08/30

10. Pantouvakis, A., Patsiouras, C.: Tourists' Selection Criteria and Motivation. Does Nationality Matter? SPOUDAI-Journal of Economics and Business 66(May 2016), 22-31 (2016).

11. Pew Research Centre: Italy on track to surpass Greece in refugee arrivals for 2016, http://www.pewresearch.org/fact-tank/2016/11/02/italy-on-track-to-surpass-greece-inrefugee-arrivals-for-2016/, last accessed 2017/08/30.

12. Popp, K.: Mediterraneam migration towards Europe: System Failure? Freedom from Fear 2016(12), 20-25 (2016), DOI: 10.18356/55293032-en.

13. Sloman, S. A.: The empirical case for two systems of reasoning. Psychological Bulletin 119(1), 3-22 (1996), DOI:10.1037//0033-2909.119.1.3.

14. Slovic, P., Weber, E. U.: Perception of Risk Posed by Extreme Events, https://www.ldeo.columbia.edu/chrr/documents/meetings/roundtable/pdf/roundtable_exec_ final.pdf, last accessed 2017/12/01.

15. Stanovich, K. E., West, R. F.: Individual Differences in Reasoning: Implications for the Rationality Debate? Heuristics and Biases 2002, 421-440 (2002), DOI: 10.1017/cbo9780511808098.026.

16. Tversky, A., Kahneman, D.: Judgment under uncertainty: Heuristics and biases. Science 185(September 1974), 1124-1131 (1974).

17. UNHCR: Over one million sea arrivals reach Europe in 2015, http://www.unhcr.org/afr/news/latest/2015/12/5683d0b56/million-sea-arrivals-reacheurope-2015.html, last accessed 2017/12/01.

18. UNHCR: Refugee sea arrivals in Greece this year approach 400,000, http://www.unhcr.org/news/latest/2015/10/560e63626/refugee-sea-arrivals-greece-yearapproach-400000.html, last accessed 2017/12/01.

19. UNHCR: Facts and Figures about Refugees. Official Report of UNHCR 2016.

20. UNHCR: Global trends, http://www.unhcr.org/globaltrends2016/, last accessed 2017/12/01.

21. UNHCR: Syria Regional Refugee Ronse, http://data.unhcr.org/syrianrefugees/regional.php, last accessed 2017/12/01. 